POETICS BEFORE PLATO 
This page intentionally left blank 


\title{
POETICS BEFORE PLATO
}

\author{
INTERPRETATION AND AUTHORITY
}

IN EARLY GREEK THEORIES OF POETRY

Grace M. Ledbetter 


\section{Copyright ( 2003 by Princeton University Press}

Published by Princeton University Press, 41 William Street,

Princeton, New Jersey 08540

In the United Kingdom: Princeton University Press,

3 Market Place Woodstock, Oxfordshire OX20 ISY

All Rights Reserved

\section{Library of Congress Cataloging-in-Publication Data}

Ledbetter, Grace M., 1965-

Poetics before Plato : interpretation and authority in early Greek

theories of poetry / Grace M. Ledbetter.

p. $\mathrm{cm}$.

Includes bibliographical references and index.

ISBN 0-691-09609-0 (acid-free paper)

1. Greek poetry-History and criticism-Theory, etc. 2. Authority

in literature. 3. Aesthetics, Ancient. 4. Poetics. I. Title.

PA3092 .L43 2002

$881^{\prime} .0109-\mathrm{dc} 21 \quad 2002016913$

British Library Cataloging-in-Publication Data is available

This book has been composed in Galliard

Printed on acid-free paper. (-)

www.pupress.princeton.edu

Printed in the United States of America

$\begin{array}{llllllllll}10 & 9 & 8 & 7 & 6 & 5 & 4 & 3 & 2 & 1\end{array}$ 
For Charles, Sarah, and Sophia 
This page intentionally left blank 